\title{
Cell growth of BG-1 ovarian cancer cells is promoted by di- $n$-butyl phthalate and hexabromocyclododecane via upregulation of the cyclin $D$ and cyclin-dependent kinase-4 genes
}

\author{
MIN-AH PARK, KYUNG-A HWANG, HYE-RIM LEE, BO-RIM YI, \\ EUI-BAE JEUNG and KYUNG-CHUL CHOI
}

\begin{abstract}
Laboratory of Veterinary Biochemistry and Immunology, College of Veterinary Medicine, Chungbuk National University, Cheongju, Chungbuk 361-763, Republic of Korea
\end{abstract}

Received September 29, 2011; Accepted December 12, 2011

DOI: $10.3892 / \mathrm{mmr} .2011 .712$

\begin{abstract}
Endocrine-disrupting chemicals (EDCs) are environmentally persistent exogenous compounds released from various industrial products such as plastics, pesticides, drugs, detergents and cosmetics. They can cause a variety of adverse effects to the reproductive, developmental, immune and nervous systems in humans and wildlife. Di- $n$-butyl phthalate (DBP) is the main compound of phthalates and is reported to inhibit estrogen receptor (ER)-mediated gene expression and to interfere with normal fetal development of the male reproductive system. Hexabromocyclododecane (HBCD or HBCDD) is one of the brominated flame retardants (BFRs) which have been widely used in plastic, electronic and textile applications and are known to cause endocrine disruption with toxicity of the nervous system. In the present study, the estrogenic effects of DBP and HBCD were examined in an ovarian cancer cell line, BG-1, expressing high levels of ER via MTT assay and semi-quantitative reverse-transcription PCR. Treatment with DBP $\left(10^{-8}-10^{-5} \mathrm{M}\right)$ or HBCD $\left(2 \times 10^{-8}-2 \times 10^{-6} \mathrm{M}\right)$ resulted in increased cell proliferation of BG-1 cells as observed with $17-\beta$ estradiol (E2). In addition, both DBP and HBCD upregulated the expression levels of cell cycle-regulatory genes, such as cyclin D and cyclin-dependent kinase-4 (cdk-4), which are downstream target genes of ER, at $6 \mathrm{~h}$ after treatment. However, the expression of the p21 gene was not altered by DBP or HBCD at any time as with E2. Taken together, these results suggest that DBP and HBCD are EDCs which have
\end{abstract}

Correspondence to: Dr Kyung-Chul Choi, Laboratory of Veterinary Biochemistry and Immunology, College of Veterinary Medicine, Chungbuk National University, Cheongju, Chungbuk 361-763, Republic of Korea

E-mail:kchoi@cbu.ac.kr

Key words: endocrine disrupting chemicals, estrogen, di-n-butyl phthalate, hexaboromocyclododecane, cyclin D, cyclin-dependent kinase-4, ovarian cancer cells apparent estrogenic activities by stimulating the cell proliferation of BG-1 cells and by inducing the expression of cyclin D and cdk-4. Our results suggest that DBP and HBCD have sufficient potency to disrupt the endocrine system and to stimulate cell growth in ER-positive cancer cells.

\section{Introduction}

Endocrine-disrupting chemicals (EDCs) are environmentally persistent exogenous compounds which may have the potential to affect the hormone balance or to disrupt the normal function of the endocrine system in humans and wildlife populations (1-3). In actuality, EDCs threaten the health of living creatures by causing a variety of adverse effects on the reproductive, developmental, immune and nervous processes and by increasing the risk of cancer incidence $(4,5)$. EDCs are released from various industrial products such as plastics, pesticides, drugs, detergents and cosmetics. In general, they have diverse chemical structures similar to that of $17 \beta$-estradiol (E2), an endogenous estrogen, and display agonistic and antagonistic effects on steroid receptors such as the estrogen receptor (ER) or the androgen receptor (AR), interfering with the actions of endogenous steroid hormones. Bisphenol-A (BPA), dioxins, dichlorodiphenyltrichloroethane (DDT), alkylphenols, polychlorinated biphenyl (PCBs), and phthalates are well-known EDCs. Among these EDCs, phthalates are chemical compounds that are mainly used as plasticizers, stabilizers, dispersants and emulsifying agents in the manufacture of diverse industrial products (6,7). Di- $n$-butyl phthalate (DBP) is one of the main phthalates, together with di-(2-ethylhexyl) phthalate (DEHP) and benzyl butyl phthalate (BBP) and are often used as a plasticizer and solvent in personal care products including perfumes and hair spray $(8,9)$. Previous studies have shown that DBP and its metabolites suppressed steroid genesis in vivo, and the treatment of DBP and DEHP to pregnant rats interfered with normal fetal development of the male reproductive system in multiple generations $(10,11)$.

Hexabromocyclododecane (HBCD or HBCDD) is one of the brominated flame retardants (BFRs) widely used in plastic, electronic and textile applications as a means of lessening the 
Table I. Primer sequences and product sizes for the semi-quantitative reverse-transcription PCR.

\begin{tabular}{|c|c|c|}
\hline Target gene & Sequences & Product size \\
\hline Cyclin D & $\begin{array}{ll}\text { Sense: } & \text { 5'-TCTAAGATGAAGGAGACCATC-3' } \\
\text { Antisense: } & \text { 5'-GCGGTAGTAGGACAGGAAGTTGTT-3' }\end{array}$ & $354 \mathrm{bp}$ \\
\hline cdk-4 & $\begin{array}{ll}\text { Sense: } & \text { 5'-TCGTGAGGTGGCTTTACTGA-3' } \\
\text { Antisense: } & \text { 5'-AGGCAGAGATTCGCTTGTGT-3' }\end{array}$ & 698 bp \\
\hline p21 & $\begin{array}{ll}\text { Sense: } & \text { 5'-AGGCACCGAGGCACTCAGAG-3' } \\
\text { Antisense: } & \text { 5'-TGACAGGTCCACATGGTCTTCC-3' }\end{array}$ & $370 \mathrm{bp}$ \\
\hline GAPDH & $\begin{array}{ll}\text { Sense: } & \text { 5'-ATGTTCGTCATGGGTGTGAACCA-3' } \\
\text { Antisense: } & \text { 5'-TGGCAGGTTTTTCTAGACGGCAG-3' }\end{array}$ & $351 \mathrm{bp}$ \\
\hline
\end{tabular}

flammability of products. HBCD is the third most commonly used BFR as it is so highly efficient that very low levels are required to reach the desired flame retardancy. However, the toxicity of HBCD and its harmful effects to the environment including lipophilic and bioaccumulating properties are currently being discussed $(12,13)$. In fact, HBCD is widely detected in various environmental samples including air, fresh water, sediments and even in blood, human milk and eggs. It has also been suggested that HBCDs exhibit agonistic effects on thyroid hormonal activity, resulting in endocrine disruption with neurologic toxicity (14-16). At present, the European Chemicals Agency (ECA) has included HBCD in the list of Substances of Very High Concern (SVHC) based on a hazard evaluation of HBCD, which was discussed in the Stockholm Convention (17).

Thus, in the present study, we investigated the estrogenic effect of DBP and HBCD in BG-1 ovarian cancer cells which have a high level of ERs to better understand the cellular mechanisms underlying their endocrine-disrupting effect as reported in previous studies. BG-1 is known to be a highly E2-responsive cancer cell line and is considered to be the most suitable in vitro model to detect the estrogenicity of EDCs $(2,18)$. Consequently, we examined the cancer cell proliferation of BG-1 cells via MTT assay and altered expression of genes related to the cell cycle via semi-quantitative reversetranscription PCR following treatment with DBP or HBCD in comparison with E2 in these cells. Cell proliferation of highly E2-responsive BG-1 cancer cells can be a prominent marker to detect the estrogenicity of DBP and HBCD. Furthermore, identification of altered gene expression may provide the basis of the underlying mechanisms involved in the endocrinedisrupting effects of these two EDCs.

\section{Materials and methods}

Cell culture and media. BG-1 human ovarian cancer cells were obtained from Dr K.S. Korach (National Institute of Environmental Health Sciences, NIH, Research Triangle Park, NC, USA). The cells were cultured in Dulbecco's modified Eagle's medium (DMEM; Hyclone Laboratories, Inc., Logan, UT, USA) supplemented with $10 \%$ heat-inactivated fetal bovine serum (FBS; Hyclone Laboratories), $100 \mathrm{U} / \mathrm{ml}$ penicillin $\mathrm{G}$ and $100 \mu \mathrm{g} / \mathrm{ml}$ streptomycin (Life Technologies, Rockville, MD, USA) at $37^{\circ} \mathrm{C}$ in a humidified atmosphere of $5 \% \mathrm{CO}_{2}-95 \%$ air. To prevent the effects of the estrogenic components of DMEM and FBS, phenol red-free DMEM supplemented with 5\% charcoal-dextran treated FBS was used to detect the estrogenicity of EDCs in the BG-1 cells.

Cell proliferation assay. Cell growth was demonstrated by MTT assay as previously demonstrated $(19,20)$. BG-1 cells $(4,000 /$ well) were plated in 96-well plates in $0.1 \mathrm{ml}$ of phenol red-free DMEM supplemented with 5\% charcoal-dextrantreated FBS medium. After incubation for $48 \mathrm{~h}$, the cells were washed and treated with E2 (Sigma-Aldrich Corp., St. Louis, MO, USA), HBCD (Sigma-Aldrich Corp.) and/or DBP (Sigma-Aldrich Corp.) at various concentrations in the medium for 6 days as described above. Dimethyl sulfoxide (DMSO, $0.1 \%$ ) in the same medium was used as a vehicle. Following treatments, the cells were then treated with $10 \mu \mathrm{l}$ of MTT solution $(5 \mathrm{mg} / \mathrm{ml})$ and incubated at $37^{\circ} \mathrm{C}$ for $4 \mathrm{~h}$. MTT-containing medium was removed and the precipitants were solubilized in DMSO $(100 \mu \mathrm{l})$. The absorbance was measured at $540 \mathrm{~nm}$ using an ELISA reader (VERSA Max, Molecular Devices, Sunnyvale, CA, USA).

Total-RNA extraction. BG-1 cells ( $3 \times 10^{5} /$ well) were cultured in 6-well plates and treated with E2, HBCD, DBP, and/or DMSO. Total-RNA was extracted at various time points $(0,6$ and $24 \mathrm{~h}$ ) using TRIzol reagents (Invitrogen Life Technologies, Carlsbad, CA, USA) according to the manufacturer's instructions. The concentration of total-RNAs was measured by a spectrophotometer (Optizen, Mecasys, Dea-jeon, Korea) at $260 / 280 \mathrm{~nm}$. One microgram of total-RNA was dissolved in diethyl pyrocarbonate-deionized water for cDNA synthesis.

Semi-quantitative reverse-transcription PCR. To synthesize cDNAs from total-RNAs for reverse transcription PCR, the reaction mixture consisted of murine leukemia virus reverse transcriptase (M-MLV RT), nonamer random primer, dNTPs, RNase inhibitor and RT buffer (all from iNtRON Biotechnology, Sungnam, Kyeonggido, Korea). The cDNA synthesis was performed at $37^{\circ} \mathrm{C}$ for $1 \mathrm{~h}$ and $95^{\circ} \mathrm{C}$ for $5 \mathrm{~min}$. Cyclin D, cdk-4, p21 and GAPDH mRNAs were amplified by using each forward and reverse primer, Taq polymerase, PCR buffer, dNTP mixture and each cDNA template via PCR as previously conducted $(2,19,20)$. The forward and reverse primer and the expected size of RT-PCR products are shown 
A

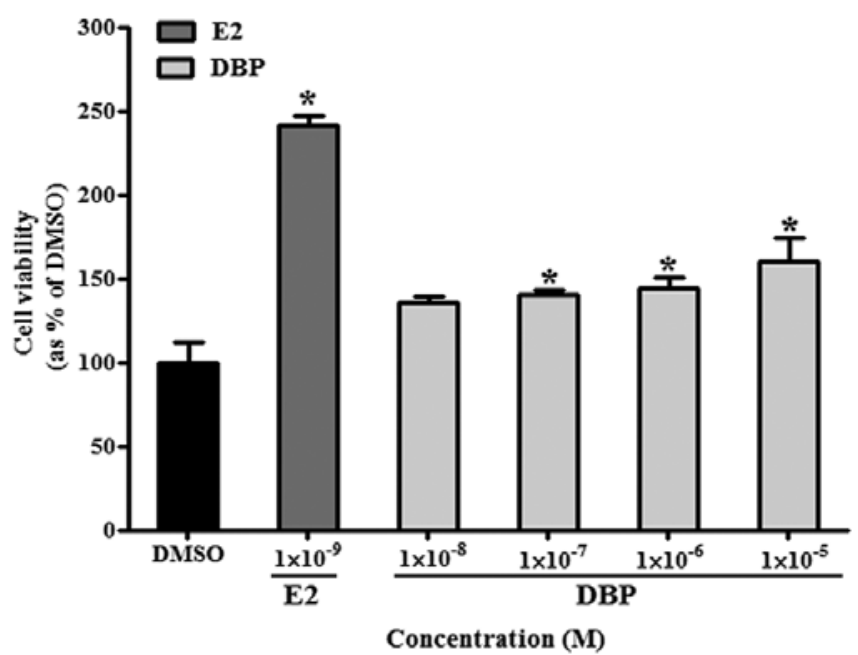

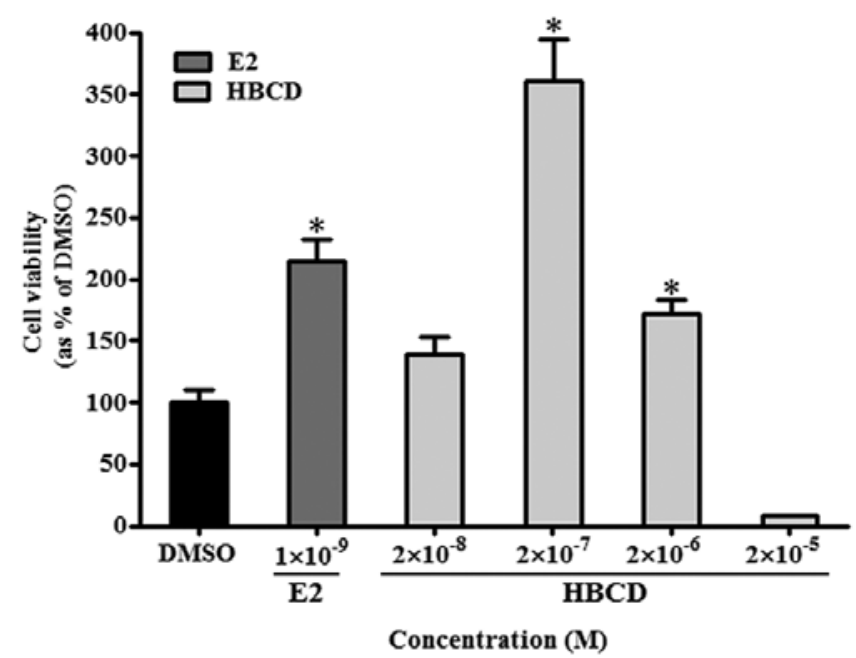

Figure 1. EDC-induced cell growth following treatment with E2, DBP or HBCD in BG-1 cells. Cells were treated with DMSO as a vehicle, E2 (10 $\left.0^{-9} \mathrm{M}\right)$, DBP $\left(10^{-8}-10^{-5} \mathrm{M}\right)$ or HBCD $\left(2 \times 10^{-8}-2 \times 10^{-5} \mathrm{M}\right)$ for 6 days, and the number of viable cells was measured using MTT assay at $540 \mathrm{~nm}$. (A) Cell proliferation of BG-1 cells after treatment with E2 or DBP. (B) Cell proliferation of BG-1 cells after treatment with E2 or HBCD. Data represent the means \pm SD of triplicate experiments. ${ }^{*} \mathrm{P}<0.05$ compared to a vehicle treated with DMSO.

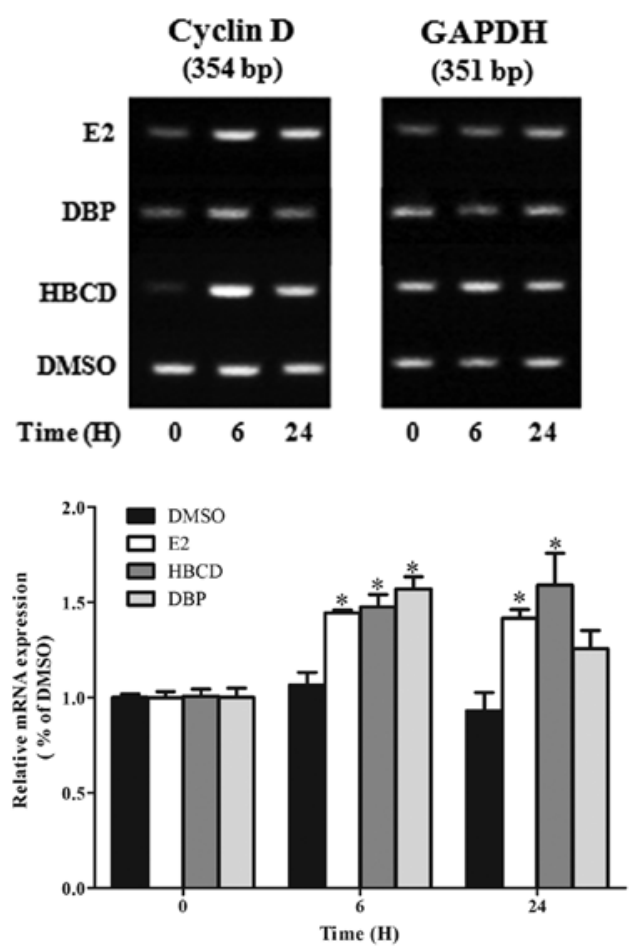

Figure 2. Altered expression levels of the cyclin D gene in BG-1 cells following treatment with E2, DBP or HBCD. BG-1 cells were seeded in 6-well plates and treated with E2 $\left(10^{-9} \mathrm{M}\right)$, DBP $\left(10^{-7} \mathrm{M}\right)$ or $\operatorname{HBCD}\left(2 \times 10^{-7} \mathrm{M}\right)$. TotalRNAs were extracted in a time-dependent manner (0, 6 and $24 \mathrm{~h})$. Expression level of cyclin D was detected using semi-quantitative reverse-transcription PCR. PCR products were run on a $1.5 \%$ agarose gel, bands were scanned and the density of the bands on the gel was quantified using Gel Doc 2000 as described in Materials and methods. Data represent the means \pm SD of triplicate experiments. $\mathrm{P}<0.05$ compared to a vehicle treated with DMSO.

in Table I. PCR products were run on a $1.5 \%$ agarose gel and the bands were compared to 100-bp ladders. The gels were scanned, and the density of the bands on the gel was quantified using Gel Doc 2000 (Bio-Rad Laboratories, Inc., Hercules, CA, USA).

Data analysis. Data are expressed as the mean \pm SD. A statistical analysis was performed using the Student t-test, two-pair comparisons. $\mathrm{P}<0.05$ was considered to denote statistical significance.

\section{Results}

Effects of DBP and HBCD on the cell proliferation of $B G-1$ cells. To evaluate the effects of DBP and HBCD on cell proliferation, BG-1 cells were cultured with treatment of vehicle

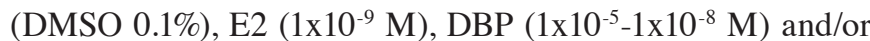
HBCD $\left(2 \times 10^{-5}-2 \times 10^{-8} \mathrm{M}\right)$ for 6 days. The results demonstrated that E2 as a positive control markedly increased the BG-1 cell proliferation in comparison with DMSO as shown in Fig. 1A and $\mathrm{B}(\mathrm{P}<0.05)$. DBP treatment gradually increased the proliferation of $\mathrm{BG}-1$ cells in a dose-responsive manner (Fig. 1A, $\mathrm{P}<0.05)$. HBCD also stimulated the growth of $\mathrm{BG}-1$ cells up to a concentration of $2 \times 10^{-6} \mathrm{M}$ (Fig. $\left.1 \mathrm{~B}\right)(\mathrm{P}<0.05)$. In particular, HBCD exhibited a potent cell proliferation activity at $2 \times 10^{-7} \mathrm{M}$, which greatly exceeded the E2 effect. On the other hand, HBCD appeared to confer strong cytotoxicity at $2 \times 10^{-5} \mathrm{M}$ as noted in Fig. $1 \mathrm{~B}(\mathrm{P}<0.05)$.

Cyclin D gene expression in BF-1 cells treated with DBP and HBCD. To evaluate the effects of DBP and HBCD on the expression levels of genes related to the cell cycle such as cyclin D, cdk-4 and p21 in BG-1 cells, we treated the cells with increasing concentrations of DBP and HBCD at $1 \times 10^{-7}$ and $2 \times 10^{-7} \mathrm{M}$, respectively, based on the cell proliferation assay. In the semi-quantitative RT-PCR experiment, the gene expression of cyclin D was significantly enhanced by treatment of E2, $\mathrm{DBP}$, or HBCD compared with a vehicle treated with DMSO for $6 \mathrm{~h}$ as shown in Fig. $2(\mathrm{P}<0.05)$. At $24 \mathrm{~h}$, treatment with 


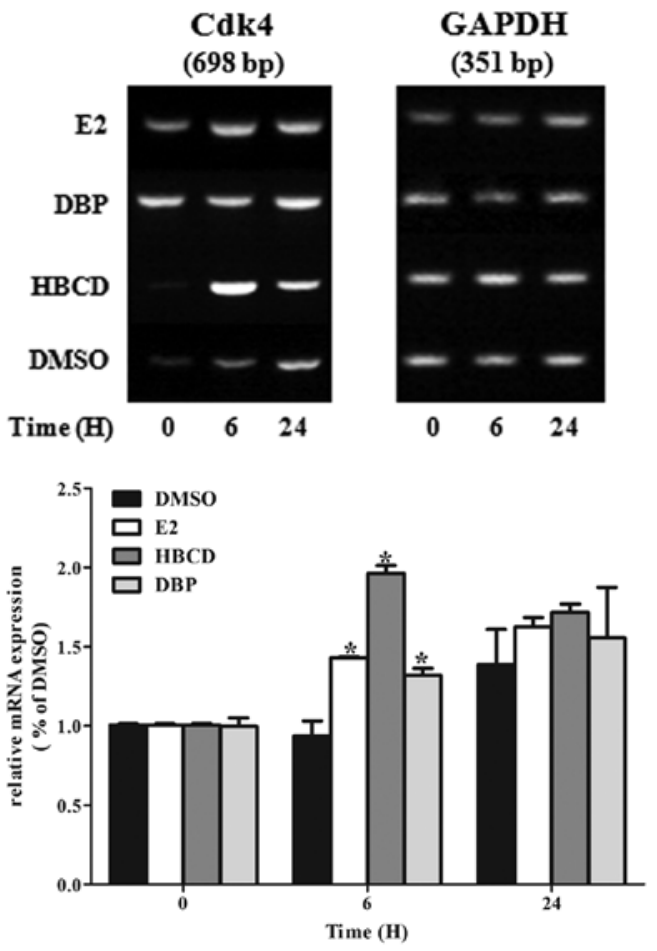

Figure 3. Altered expression levels of the cdk-4 gene following treatment with E2, DBP or HBCD. BG-1 cells were seeded in 6-well plates and treated with E2 $\left(10^{-9} \mathrm{M}\right)$, DBP $\left(10^{-7} \mathrm{M}\right)$ or HBCD $\left(2 \times 10^{-7} \mathrm{M}\right)$. Total-RNAs were extracted in a time-dependent manner $(0,6$ and $24 \mathrm{~h})$. The expression level of cdk-4 was detected using semi-quantitative reverse-transcription PCR. Data represent the means $\pm \mathrm{SD}$ of triplicate experiments. ${ }^{*} \mathrm{P}<0.05$ compared to a vehicle treated with DMSO.

E2, HBCD or DBP significantly stimulated the expression of Cdk-4 as well in ER-positive BG-1 ovarian cancer cells.

Cdk-4 gene expression in BF-1 cells treated with DBP and $H B C D$. In parallel with an increase in the expression level of cyclin D by HBCD and DBP, the expression of the cdk- 4 gene was also increased (Fig. 3). In particular, cdk-4 gene expression was significantly increased by HBCD or DBP treatment at $6 \mathrm{~h}$ compared to a vehicle (DMSO treatment, $\mathrm{P}<0.05$ ) as shown in Fig. 3. However, the difference in the expression level of the Cdk-4 gene was apparently decreased at $24 \mathrm{~h}$ between the vehicle and EDC treatment.

p21 expression in $B G-1$ cells treated with $D B P$ and $H B C D$. The expression level of p21, a cyclin D-cdk-4 complex inhibitor gene, was further examined following treatment with E2, HBCD and DBP. The expression of p21 was suppressed by E2 compared to DMSO treatment at $6 \mathrm{~h}$ as noted in Fig. 4 $(\mathrm{P}<0.05)$. However, its expression in BG-1 ovarian cancer cells was not significantly altered by HBCD or DBP treatment compared to a vehicle of DMSO treatment at all time points (Fig. 4).

\section{Discussion}

Previous studies have reported that EDCs pose a high human health risk by disturbing the hormone balance in the endo-

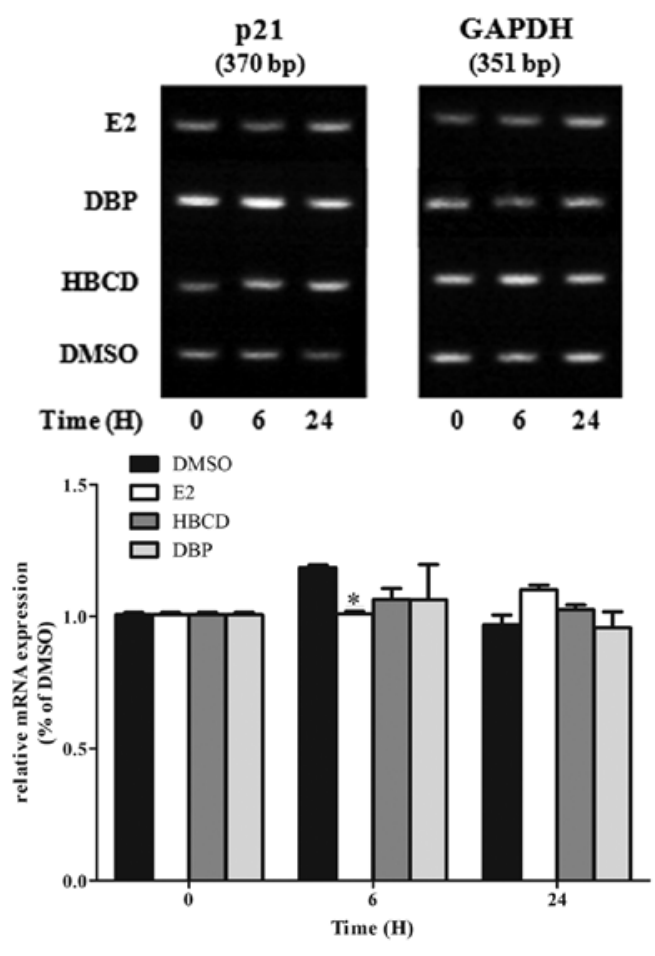

Figure 4. Altered expression levels of the p21 gene following treatment with E2, DBP or HBCD. BG-1 cells were seeded in 6-well plates and treated with E2 $\left(10^{-9} \mathrm{M}\right)$, DBP $\left(10^{-7} \mathrm{M}\right)$ or HBCD $\left(2 \times 10^{-7} \mathrm{M}\right)$. Total-RNAs were extracted in a time-dependent manner $(0,6$ and $24 \mathrm{~h})$. Expression level of p21 was detected by using semi-quantitative reverse-transcription PCR. Data represent the means $\pm \mathrm{SD}$ of triplicate experiments. ${ }^{*} \mathrm{P}<0.05$ compared to a vehicle treated with DMSO.

crine system of body organs. Moreover, the cell transformation caused by consistent exposure to EDCs may increase the risk of cancer incidence $(21,22)$. EDCs are known to induce a hormone imbalance by directly interacting with various hormone receptors such as ER, progesterone receptor (PR), AR and thyroid receptor (ThR) as their agonists and antagonists. The main property and harmful factor of many EDCs are their estrogenic effects as they often interfere with endogenous estrogen by having chemical structures similar to E2. In addition, mimicking estrogen function results in fatal damaging responses, i.e., endocrine disruption or tumor promotion (23-25). E2, an endogenous estrogen, is known to mediate cellular responses via two ERs, ER $\alpha$ and ER $\beta$. Therefore, the estrogenic effect of EDCs can be categorized according to their mediating pathway via ER $\alpha$ or ER $\beta$. For instance, diethylstilbesterol (DES), one of the EDCs and a synthetic estrogen, has been reported to inhibit follicle formation and development via ER $\alpha$. On the other hand, it induces polyovular follicles via ER $\beta$ (26). In the present study, we selected BG-1, a human ovarian cancer cell line, to detect the estrogenicity of EDCs as it is a highly estrogen-responsive cell line due to its strong expression of both ER $\alpha$ and ER $\beta(2,18)$. We also confirmed its estrogen dependence in the cell proliferation assay, in which the growth of BG-1 cells were increased more than two-fold by a low-dose treatment of E2 $\left(1 \times 10^{-9} \mathrm{M}\right)$.

In the present study, we examined the estrogenicity of two EDCs, DBP and HBCD, for which harmful effects have been recently disclosed. DBP has reported to disrupt the endocrine 
system and generate transformations in the growth and development of male reproductive organs by causing Leydig cell proliferation, germ cell degeneration and testosterone decrease in the fetal testis (27-30). Additionally, HBCD is known to increase cell proliferation of MCF-7 cells and the expression of TFF1, an estrogen-dependent gene, in breast cancer cells. Furthermore, it appears to transform the expression level of genes associated with cell proliferation and DNA methylation as does E2 (31-33). We also examined whether DBP and HBCD have an estrogenic effect by stimulating the cell proliferation of E2-responsive BG-1 ovarian cancer cells. Our data showed that the treatment of cells with $\mathrm{DBP}\left(10^{-8}-10^{-5} \mathrm{M}\right)$ or HBCD $\left(2 \times 10^{-8}-2 \times 10^{-6} \mathrm{M}\right)$ obviously increased the cell proliferation as did E2.

Accordingly, we determined whether these EDCs promote cell proliferation by altering the expression level of cell cycleregulating genes such as cyclin D, cdk-4 and p21, which are known downstream targets of E2 and ER. In cell cycling pathways, cyclin D and cdk-4 form a complex and promote cell cycle progression through the G1 phase. p21, the cdk inhibitor, disrupts the formation of the cyclin-cdk complex and inhibits G1/S transition (34,35). E2 is reported to stimulate cellular proliferation, PR expression and morphological differentiation in the endometrial Ishikawa cancer cell line by stimulating the transition of cell cycle via upregulation of cyclin D and cyclin A and downregulation of p21, p27 and p53 $(36,37)$. Our previous results also showed that the expression levels of the cyclin D and cdk-4 genes in the BG-1 cell line were significantly increased with E2 $\left(10^{-7} \mathrm{M}\right)$ or BPA $\left(10^{-5} \mathrm{M}\right)$ treatment for $24 \mathrm{~h}$ (2). In this study, DBP and HBCD actually upregulated the expression levels of cyclin D and cdk-4 but had no effect on the expression of p21.

In conclusion, DBP and HBCD are EDCs which exhibited estrogenic activities in an estrogen-dependent cancer cell line, BG-1, by stimulating cell proliferation and by upregulating the expression of cell cycle-regulating genes, cyclin D and cdk-4. In addition, our results support that DBP and HBCD may have sufficient potency to disrupt the endocrine system and to stimulate tumorigenesis as previously reported by the risk assessment of EDCs. A further study is required to elucidate the specific mechanisms of DBP and HBCD in the disruption of the endocrine and reproductive systems in vitro and in vivo.

\section{Acknowledgements}

This study was supported by a National Research Foundation of Korea (NRF) grant funded by the Ministry of Education, Science and Technology (MEST) of Korea government (no. 2011-0015385).

\section{References}

1. Choi KC and Jeung EB: The biomarker and endocrine disruptors in mammals. J Reprod Dev 49: 337-345, 2003.

2. Hwang KA, Park SH, Yi BR and Choi KC: Gene alterations of ovarian cancer cells expressing estrogen receptors by estrogen and bisphenol a using microarray analysis. Lab Anim Res 27: 99-107, 2011

3. Gee RH, Charles A, Taylor N and Darbre PD: Oestrogenic and androgenic activity of triclosan in breast cancer cells. J Appl Toxicol 28: 78-91, 2008.
4. Bencko V: Human exposure to endocrine disrupters: carcinogenic risk assessment. Folia Histochem Cytobiol 39: 24-25, 2001

5. Brevini TA, Zanetto SB and Cillo F: Effects of endocrine disruptors on developmental and reproductive functions. Curr Drug Targets Immune Endocr Metabol Disord 5: 1-10, 2005.

6. Thasni KA, Rojini G, Rakesh SN, Ratheeshkumar T, Babu MS, Srinivas G, Banerji A and Srinivas P: Genistein induces apoptosis in ovarian cancer cells via different molecular pathways depending on Breast Cancer Susceptibility gene-1 (BRCA1) status. Eur J Pharmacol 588: 158-164, 2008

7. Xu Y, Yu RM, Zhang X, Murphy MB, Giesy JP, Lam MH, Lam PK, Wu RS and Yu H: Effects of PCBs and MeSO2-PCBs on adrenocortical steroidogenesis in H295R human adrenocortical carcinoma cells. Chemosphere 63: 772-784, 2006.

8. Kim YH, Kim SH, Lee HW, Chae HD, Kim CH and Kang BM: Increased viability of endometrial cells by in vitro treatment with di-(2-ethylhexyl) phthalate. Fertil Steril 94: 2413-2416, 2010.

9. Harris CA, Henttu P, Parker MG and Sumpter JP: The estrogenic activity of phthalate esters in vitro. Environ Health Perspect 105: 802-811, 1997.

10. Shanle EK and Xu W: Endocrine disrupting chemicals targeting estrogen receptor signaling: identification and mechanisms of action. Chem Res Toxicol 24: 6-19, 2011.

11. Ghisari M and Bonefeld-Jorgensen EC: Effects of plasticizers and their mixtures on estrogen receptor and thyroid hormone functions. Toxicol Lett 189: 67-77, 2009.

12. Daston GP, Cook JC and Kavlock RJ: Uncertainties for endocrine disrupters: our view on progress. Toxicol Sci 74: 245-252, 2003.

13. Ronisz D, Finne EF, Karlsson H and Forlin L: Effects of the brominated flame retardants hexabromocyclododecane (HBCDD), and tetrabromobisphenol A (TBBPA), on hepatic enzymes and other biomarkers in juvenile rainbow trout and feral eelpout. Aquat Toxicol 69: 229-245, 2004.

14. de Wit CA, Herzke D and Vorkamp K: Brominated flame retardants in the Arctic environment - trends and new candidates. Sci Total Environ 408: 2885-2918, 2010.

15. Ibhazehiebo K, Iwasaki T, Shimokawa N and Koibuchi N: 1,2,5,6,9,10-alphaHexabromocyclododecane (HBCD) impairs thyroid hormone-induced dendrite arborization of Purkinje cells and suppresses thyroid hormone receptor-mediated transcription. Cerebellum 10: 22-31, 2011.

16. Ibhazehiebo K, Iwasaki T, Xu M, Shimokawa N and Koibuchi N: Brain-derived neurotrophic factor (BDNF) ameliorates the suppression of thyroid hormone-induced granule cell neurite extension by hexabromocyclododecane (HBCD). Neurosci Lett 493: 1-7, 2011.

17. Colles A, Koppen G, Hanot V, Nelen V, Dewolf MC, Noel E, Malisch R, Kotz A, Kypke K, Biot P, Vinkx C and Schoeters G: Fourth WHO-coordinated survey of human milk for persistent organic pollutants (POPs): Belgian results. Chemosphere 73: 907-914, 2008

18. Park SH, Kim KY, An BS, Choi JH, Jeung EB, Leung PC and Choi KC: Cell growth of ovarian cancer cells is stimulated by xenoestrogens through an estrogen-dependent pathway, but their stimulation of cell growth appears not to be involved in the activation of the mitogen-activated protein kinases ERK-1 and p38. J Reprod Dev 55: 23-29, 2009.

19. Yi BR, O SN, Kang NH, Hwang KA, Kim SU, Jeung EB, Kim YB, Heo GJ and Choi KC: Genetically engineered stem cells expressing cytosine deaminase and interferon-beta migrate to human lung cancer cells and have potentially therapeutic anti-tumor effects. Int J Oncol 39: 833-839, 2011.

20. Yi BR, Kang NH, Hwang KA, Kim SU, Jeung EB and Choi KC: Antitumor therapeutic effects of cytosine deaminase and interferon-\{beta\} against endometrial cancer cells using genetically engineered stem cells in vitro. Anticancer Res 31: 2853-2861, 2011.

21. Ulbrich B and Stahlmann R: Developmental toxicity of polychlorinated biphenyls (PCBs): a systematic review of experimental data. Arch Toxicol 78: 252-268, 2004.

22. Stefanidou M, Maravelias C and Spiliopoulou C: Human exposure to endocrine disruptors and breast milk. Endocr Metab Immune Disord Drug Targets 9: 269-276, 2009.

23. Kashima H, Shiozawa T, Miyamoto T, Suzuki A, Uchikawa J, Kurai M and Konishi I: Autocrine stimulation of IGF1 in estrogeninduced growth of endometrial carcinoma cells: involvement of the mitogen-activated protein kinase pathway followed by up-regulation of cyclin D1 and cyclin E. Endocr Relat Cancer 16: $113-122,2009$ 
24. Choi JH, Lee KT and Leung PC: Estrogen receptor alpha pathway is involved in leptin-induced ovarian cancer cell growth. Carcinogenesis 32: 589-596, 2011.

25. Albanito L, Madeo A, Lappano R, Vivacqua A, Rago V, Carpino A, Oprea TI, Prossnitz ER, Musti AM, Ando S and Maggiolini M: G protein-coupled receptor 30 (GPR30) mediates gene expression changes and growth response to 17 beta-estradiol and selective GPR30 ligand G-1 in ovarian cancer cells. Cancer Res 67: $1859-1866,2007$.

26. Craig ZR, Wang W and Flaws JA: Endocrine disrupting chemicals in ovarian function: effects on steroidogenesis, metabolism and nuclear receptor signaling. Reproduction 142: 633-646, 2011.

27. Takamiya M,Lambard S and Huhtaniemi IT: Effect of bisphenol A on human chorionic gonadotrophin-stimulated gene expression of cultured mouse Leydig tumour cells. Reprod Toxicol 24: 265-275, 2007.

28. Mylchreest E, Wallace DG, Cattley RC and Foster PM: Dosedependent alterations in androgen-regulated male reproductive development in rats exposed to Di (n-butyl) phthalate during late gestation. Toxicol Sci 55: 143-151, 2000.

29. Saffarini CM, Heger NE, Yamasaki H, Liu T, Hall SJ and Boekelheide K: Induction and persistence of abnormal testicular germ cells following gestational exposure to Di-(n-butyl) phthalate in p53-null mice. J Androl: August 25, 2011 (Epub ahead of print).

30. Kruger T, Long M and Bonefeld-Jorgensen EC: Plastic components affect the activation of the aryl hydrocarbon and the androgen receptor. Toxicology 246: 112-123, 2008.

31. Dorosh A, Ded L, Elzeinova F and Peknicova J: Assessing oestrogenic effects of brominated flame retardants hexabromocyclododecane and tetrabromobisphenol A on MCF-7 cells. Folia Biol (Praha) 57: 35-39, 2011.
32. Aniagu SO, Williams TD and Chipman JK: Changes in gene expression and assessment of DNA methylation in primary human hepatocytes and HepG2 cells exposed to the environmental contaminants-Hexabromocyclododecane and 17-beta oestradiol. Toxicology 256: 143-151, 2009.

33. Eriksson P, Fischer C, Wallin M, Jakobsson E and Fredriksson A: Impaired behaviour, learning and memory, in adult mice neonatally exposed to hexabromocyclododecane (HBCDD). Environ Toxicol Pharmacol 21: 317-322, 2006.

34. Watanabe J, Kamata Y, Seo N, Okayasu I and Kuramoto H: Stimulatory effect of estrogen on the growth of endometrial cancer cells is regulated by cell-cycle regulators. J Steroid Biochem Mol Biol 107: 163-171, 2007.

35. Ptak A, Wrobel A and Gregoraszczuk EL: Effect of bisphenol$\mathrm{A}$ on the expression of selected genes involved in cell cycle and apoptosis in the OVCAR-3 cell line. Toxicol Lett 202: 30-35, 2011.

36. Boehme K, Simon S and Mueller SO: Gene expression profiling in Ishikawa cells: a fingerprint for estrogen active compounds. Toxicol Appl Pharmacol 236: 85-96, 2009.

37. Bredhult C, Backlin BM and Olovsson M: Effects of some endocrine disruptors on the proliferation and viability of human endometrial endothelial cells in vitro. Reprod Toxicol 23: 550-559, 2007. 